\title{
POLACY NA URALU W LATACH 60.-80. XIX WIEKU W ŚWIETLE WSPOMNIEŃ WLADYSLAWA ZAHORSKIEGO
}

I ntensywniejsze od kilku ostatnich dekad badania polskich i rosyjskich historyków nad polskimi zesłańcami w XIX w. na Syberii oraz, choć w mniejszym zakresie, w innych rejonach Rosji, przyniosły wiele nowych ustaleń, znacznie poszerzających dotychczasowy stan wiedzy ${ }^{1}$. Można zaryzykować tezę, iż nastąpił w tych badaniach zarówno ilościowy, jak i jakościowy skok, polegający przede wszystkim na rozszerzeniu podstawy źródłowej o archiwalia rosyjskie, w tym zwłaszcza źródła wytworzone przez lokalne władze, oraz na powiększeniu spectrum zadawanych pytań badawczych. W rezultacie znacznie więcej dzisiaj wiemy o losach pojedynczych zesłańców, dysponujemy bardziej wiarygodnymi danymi o ich liczbie i mobilności, o roli wśród miejscowej ludności i wzajemnych z nią relacjach, o procesach społeczno-ekonomicznej adaptacji w nowej rzeczywistości. Owocujące wieloma publikacjami zainteresowanie naukowców z uczelni rosyjskich, znajdujących się na obszarach, gdzie społeczność zesłańcza z ziem dawnego państwa polsko-litewskiego pozostawiła swój ślad, jest też częścią szerszego zjawiska społecznego: potrzeby poznawania własnej historii przez narody i grupy etniczne zamieszkujące Rosję, potrzeby, na którą, choć to nie jedyna inspiracja, historycy starają się odpowiedzieć ${ }^{2}$.

Niniejszy artykuł analizuje przekazy o zesłańcach postyczniowych w Ufie w świetle nieopublikowanych dotąd wspomnień Władysława Zahorskiego (1858-1926) - znanego wileńskiego lekarza, działacza kulturalnego i społecznego (m.in. prezesa Towarzystwa Przyjaciół Nauk w Wilnie) oraz autora wielu prac o historii i zabytkach Wilna ${ }^{3}$. Źródło jest cenne, niewiele bowiem wiadomo o warunkach życia zesłanych w związku z powstaniem styczniowym do guberni

\footnotetext{
${ }^{1}$ Najnowszy przegląd literatury zob.: W. Caban, Zsytka Polaków na Syberię w XIX wieku. Przegląd publikacji polskich i rosyjskich/radzieckich, „Przegląd Historyczny” 2014, t. 105, z. 4, s. 99-123.

2 Piszą o tym wprost np.: Poljaki w Piermskom kraie: oczerki istorii i etnografii, Sankt Peterburg 2009, s. 6-7.

${ }^{3}$ W. Zahorski, Moje wspomnienia, t. I-IV, Biblioteka Narodowa (dalej: BN), rkps II. 10.455. Ich edycję przygotowała do wydania autorka niniejszego artykułu.
} 
uralskich 4 . I choć opowieść Zahorskiego dotyczy okresu, kiedy on sam był kilkuletnim chłopcem, to pamiętnik zawiera nieznane i jak się wydaje cenne informacje (inna sprawa, że nie zawsze jesteśmy pewni ich wiarygodności), które uzupełniają dotychczasowy stan wiedzy o życiu zesłańców, a zważywszy, iż była pisana u schyłku życia (w latach 20. XX w.), stwarza perspektywę poznawczą dotyczącą zsyłki w świadomości pokolenia dzieci powstańców 1863 r., do którego Władysław Zahorski należał5.

Zahorski zdążył opisać historię pierwszych 34 lat swego życia: dzieciństwo w Święcianach i Wilnie, młodość i pierwsze lata dorosłego życia przebyte w głębi Rosji oraz początki stałego pobytu na Litwie po powrocie do kraju. Z owych 34 lat, 25 autor spędził w Rosji, z czego dwadzieścia na Uralu (Ufa: 1864-1867 i 1872-1877, Perm: 1877 r., Jekaterynburg: 1884 r., Czelabińsk: 1885-1892) oraz pięć w Moskwie (1878-1883), gdzie studiował medycynę.

Opis pobytu w Rosji zajmuje trzy czwarte z około tysiąca stron tekstu i w przeważającym stopniu dotyczy, poza losami i przeżyciami samego autora, realiów życia w Rosji, wyglądu miast, zabytków, poznanych Rosjan (kolegów w szkole, nauczycieli i profesorów, znajomych w pracy, pacjentów, znanych ludzi). Zawsze jednak Zahorski pamięta, by napisać o spotkanych w Rosji rodakach, dzięki czemu „Wspomnienia” dają panoramę niemal wszystkich kategorii migrantów z Królestwa Polskiego i ziem zabranych przebywających w głębi Cesarstwa. Na kartach pamiętnika znajdujemy więc i zesłańców politycznych po powstaniu styczniowym (także unitów) oraz poborowych żołnierzy, i dobrowolnych imigrantów, przebywających w Rosji, bądź na stałe ${ }^{6}$ jak inżynierowie, lekarze, oficerowie, a także urzędnicy i rzemieślnicy, bądź na czas określony - uczniowie, studenci, artyści. Są nawet potomkowie smoleńskiej szlachty przesiedlonej w XVII w., brakuje jedy-

${ }^{4}$ Kilka miesięcy w 1863 r. spędził w Ufie Jakub Gieysztor (Pamiętniki Jakuba Gieysztora z lat 1857-1865, Wilno 1913, t. 2, s. 103-105), w Ufie i Orenburgu przebywał też w 1863 r. Tadeusz Korzon (Mój pamiętnik przedhistoryczny, Kraków 1912, s. 110-120). O nieznanej spuściźnie zesłańca na Uralu zob. W. Caban, L. Michalska-Bracha, „Orenburski domek” Stanisława Miaskowskiego. Z badań nad lwowską kolekcją listów zesłańca postyczniowego (1863-1867), [w:] Zesłańcy postyczniowi w Imperium Rosyjskim. Studia dedykowane profesor Wiktorii Śliwowskiej, red. E. Niebelski, Lublin-Warszawa 2008, s. 177-190. Natomiast najpełniejszy obraz daje praca: W.W. Latypowa, Poljaki na Jużnom Urale (XVII-naczało XX weka). Oczerki istoriko-kul'turnogo nasledija, Ufa 2010. Pragnę podziękować prof. Wiesławowi Cabanowi za sprowadzenie i udostępnienie mi tej książki.

${ }^{5}$ Ze wspomnień Zahorskiego korzystała badaczka z Ufy Walentyna W. Latypowa w pracach: W.W. Latypowa, Polskije ssylnye na Jużnom Urale posl 'e wosstanija 1863-1864 godow i ich wzaimootnoszenija c mestnym naseleniem, [w:] Polacy a Rosjanie. Materiaty z konferencji „Polska-Rosja. Rola polskich powstań narodowych w ksztattowaniu wzajemnych wyobrażeń". Warszawa-Plock, 14-17 maja 1998, pod red. T. Epszteina, Warszawa 2000, s. 278-279; taż, Poljaki..., s. 126, 165-166.

${ }^{6}$ Nie zawsze to oznacza na całe życie, jakaś część migrantów (na obecnym etapie badań trudno określić jak duża), dopracowawszy się emerytury wracała w rodzinne strony (przykładem choćby ojciec Zahorskiego). 
nie chłopskich kolonistów i robotników przemysłowych, ale ich napływ nastąpił w czasach, gdy Zahorski wrócił już na Litwę ${ }^{7}$ W sumie pamiętnikarz wymienia ponad 300 poznanych osób pochodzących z obszaru dawnej Rzeczypospolitej Obojga Narodów, z czego w uralskich partiach pamiętnika przywołuje z imienia i/lub nazwiska, bądź wskazuje personalnie poprzez narodowość, np. ,inżynier Polak”, 154 osoby. Część z nich to zesłańcy wraz z członkami swych rodzin.

Przyszły pamiętnikarz przybył do Ufy z rodzicami i rodzeństwem albo jesienią 1863 r., jak sam pisze, albo w 1864 r., na co wskazuje spis służby ojca ${ }^{8}$. Okoliczności znalezienia się Zahorskich w Ufie budzą pewne wątpliwości, bowiem według „Wspomnień”, ojciec został „,eportowany”, na wyraźne polecenie samego Murawiewa, za zorganizowanie w swoim domu w Święcianach śniadania patriotycznego ${ }^{9}$, zaś rosyjskie spisy służby Bronisława Zahorskiego, który w Święcianach był lekarzem na etacie wileńskiego oddziału Ministerstwa Dóbr Państwowych, odnotowują, że od 1 stycznia 1864 r. przebywał on jako lekarz na posadzie tegoż ministerstwa, najpierw w Orenburgu, a następnie (nie jest podane od jakiego miesiąca) w Ufie i nie ma żadnych obciążeń politycznych ${ }^{10}$. Przyjmijmy, na obecnym etapie badań hipotezę, z braku potwierdzenia wyroku w aktach, że Bronisław Zahorski został skazany w trybie administracyjnym na zamieszkanie w guberni orenburskiej (Ufa była wówczas miastem powiatowym) bez nadzoru policyjnego, albo też nadzór został szybko zdjęty, inaczej bowiem nie mógłby oficjalnie podjąć pracy $\mathrm{i}$ to p.o. gubernialnego inspektora lekarskiego, nie uczestniczyłby w żadnych zebraniach Rosjan, syn zaś pisze, że ojca „stale wybierano na starszyne klubu szlacheckiego" (nie musi to dotyczyć pierwszych lat pobytu). Rodzina Zahorskich, której los pamiętnikarz wplata w narrację o zesłańcach, dość szybko zaczęła żyć w Ufie na lepszych warunkach niż pozostali wygnańcy, o których Władysław pisze, a stanowi raczej jeden z wariantów zesłańczych losów, wymagających odrębnego potraktowania.

${ }^{7}$ O emigracji zarobkowej do Rosji zob.: K. Groniowski, Emigracja z ziem zaboru rosyjskiego (1864-1918), [w:] Emigracja z ziem polskich w czasach nowożytnych (XVIII-XX w.), red. A. Pilch, Warszawa 1984, s. 223-230.

${ }^{8}$ Za pomyłkę należy uznać informację Latypowej, podaną za pamiętnikiem, jakoby Zahorscy przybyli do Ufy w latach 1861-1862 (W.W. Latypowa, Polskije ssylnye..., s. 272); taż, Poljaki..., s. 126.

${ }^{9}$ W. Zahorski, $d z$. cyt., rozdz. II, k. 19-23, 27-29. Mało jednak prawdopodobne, aby takie śniadanie patriotyczne, czyli spotkanie obywatelstwa i przedstawicieli innych stanów mogło mieć miejsce w okresie powstania, i to za rządów Murawiewa. Nie znalazłam też dotąd informacji w aktach o zesłaniu Bronisława Zahorskiego.

${ }^{10}$ Archiwum Władysława Zahorskiego. „Dokumenty osobiste Bronisława Zahorskiego i jego żony Marii z Jawłowskich", BN, rkps IV 10.451, mikrofilm 30866-30875 (formularnyj spisok), 30863. Zahorski pisze o pomocy jakiej udzielił ojcu urzędnik ministerialny w zamianie miejsca zesłania z Orenburga do Ufy (W. Zahorski, $d z$. cyt., k. 22), natomiast czy możliwe jest zatarcie w aktach pierwotnej przyczyny znalezienia się lekarza w Ufie, nie umiem odpowiedzieć. 
Znane Zahorskiemu uralskie gubernie - ufijska i orenburska reprezentowały mieszany, zesłańczo-zarobkowy obszar obecności w nich ludności z ziem dawnej Rzeczypospolitej Obojga Narodów ${ }^{11}$. Zesłańców politycznych osadzano na Uralu począwszy od końca XVIII w. (jeńcy z konfederacji barskiej) i w ciągu całego XIX w., zaś dobrowolni osadnicy, albo wywodzili się z byłych zesłańców, albo przybywali, zwłaszcza od lat. 80., do pracy w rozwijającym się dynamicznie przemyśle i przy budowie kolei ${ }^{12}$.

Największa liczba zesłańców pojawiła się w 1863 i 1864 r. (przybywali od końca 1860 do 1867 r.). Po barszczanach i powstańcach listopadowych, był to trzeci etap polskiej zsyłki na Ural. Większość zesłanych na Ural kierowano do guberni orenburskiej i ufijskiej, pod kontrolę tzw. ,nadzornych komand”. Jak duża była to grupa, trudno powiedzieć precyzyjnie. Nikt z historyków mających dostęp do archiwów rosyjskich nie próbował dotąd oszacować jej wielkości. Podawane informacje o liczbie zesłańców są wyrywkowe - dotyczą jednego roku, określonego miejsca lub określonej grupy zesłanych (np. tylko objętych nadzorem policyjnym). Wiemy dzięki pracy Walentyny Latypowej, że w $1865 \mathrm{r}$. w miastach obu guberni znajdowało się 485 zesłańców pod nadzorem policji, z czego większość (brak informacji) w Ufie, pozostali zaś, według liczby, w: Sterlitamaku, Orenburgu, Czelabińsku, Troicku, Belebeju, Birsku i Werchneuralsku. Według badaczki, przeważali liczebnie nad pozostałymi, czyli chłopami, mieszczanami i innymi kategoriami ludności, których miejscowe władze osiedlały na państwowej ziemi na wsi. Od 21 lutego do 28 maja 1864 r. do pow. czelabińskiego przybyło 212 osób, a do pow. ufijskiego 22 osoby $^{13}$. Powroty przed pierwszą amnestią w $1867 \mathrm{r}$. mogły dotyczyć wyjątkowych sytuacji (np. Jakub Gieysztor), co oznacza, że w 1865 r. w miastach i na wsi było przynajmniej 719 zesłanych w wyniku powstania styczniowego. Jak jednak mogą to być dalekie od rzeczywistości szacunki, uzmysławia porównanie tej liczy do informacji, iż według organizatorów wystawy w Orenburgu w 1993 r., poświęconej zesłańcom styczniowym, w guberni orenburskiej znalazło się w wyniku zsyłki (1862-1867) ok. $3500{\text { Polaków }{ }^{14} .}^{14}$

${ }^{11}$ Można wyróżnić kilka typów obecności migrantów z guberni zachodnich i Królestwa Polskiego w Rosji: 1) kolonie w dużych miastach, mające najstarszą i najbardziej zróżnicowaną społecznie i zawodowo Polonię, 2) mniejsze ośrodki z uczelniami i polskimi studentami, 3) rejony zesłania, gdzie dominowali zesłańcy (Syberia), 4) ośrodki przemysłowe i obszary inwestycji (np. kolej), cele dobrowolnej migracji zarobkowej, 5) siedziby wojska. Temat polskiej migracji w Rosji ma swoją literaturę, ciągle jednak nie wyczerpuje tematu. Syntetyczne ujęcie: Z. Łukawski, Polacy w Rosji: 1863-1914, Wrocław-Warszawa-Kraków 1978; zob. też: A Kijas, Polacy w Rosji od XVII wieku do 1917 roku. Stownik biograficzny, Warszawa-Poznań 2000.

${ }^{12}$ Opisowi kolejnych etapów migracji poświęcona jest książka W.W. Latypowej Poljaki....

${ }^{13}$ Najwięcej było chłopów - 106, mieszczan - 90, 14 dworian i szlachciców, 2 cudzoziemców. W.W. Latypowa, Poljaki..., s. 123. Autorka wskazuje na obecność wielu więcej zesłanych.

${ }^{14}$ L. Michalska-Bracha, $d z$. cyt., s. 178. 
Pozycję zesłańców na Uralu określał przede wszystkim charakter kary. Do wewnętrznych guberni Rosji kierowano za lżejsze winy. Ufa, Orenburg znajdowały się wśród kilku najmniej oddalonych od dawnych ziem Rzeczypospolitej miejsc zesłania (podróż Jakuba Gieysztora do Ufy trwała dwa tygodnie). Kierowano tam na zamieszkanie, na ogół czasowe. Wielu, jak podaje Latypowa, zesłano $\mathrm{w}$ trybie administracyjnym, na podstawie podejrzenia o „niepewne zachowania polityczne". Zesłanie miało charakter prewencyjny, choć można postawić pytanie, czy przy okazji nie było świadomie wykorzystywaną okazją do przeniesienia w głąb Rosji ludzi wykształconych, których tam brakowało (np. lekarzy). Większość zesłanych podlegała policyjnemu nadzorowi, co wiązało się ze znaczącymi dla ich sytuacji życiowej ograniczeniami, np. zakazem pracy.

W zasięgu kontaktów rodziny Władysława Zahorskiego znajdował się niewielki procent $\mathrm{z}$ tych, którzy odbywali karę $\mathrm{w}$ Ufie. $\mathrm{Z}$,dość licznego grona wygnańców z Królestwa, Litwy, Wołynia” (II/33) ${ }^{15}$ jacy przebywali w mieście, autor „Wspomnień” pamięta nazwiska 24 (w tym swego ojca oraz dwie osoby przybyłe z Syberii, które po niedługim pobycie w Ufie wróciły do kraju), wielu innych nazwiska się zatarły. Razem z 19 wymienionymi członkami rodzin i jedną służącą stanowili grupę 43 osób. Kolonia w Ufie utrzymywała kontakt z księżmi zesłanymi do Birska, których liczbę Zahorski określa raz jako „kilkunastu”, innym razem „około 20” lub „,kilkudziesięciu” ${ }^{16}$. Wspomina też, że w drodze na zesłanie płynęło z nimi „kilkunastu Polaków zesłańców, niektórzy z żonami i dziećmi”, nie wiemy jednak, czy zamieszkali w Ufie. W Permie, gdzie Zahorscy zamieszkali w 1877 r., ,Z wygnańców nikt tu prawie nie pozostał”, zapamiętał biskupa łucko-żytomierskiego Kacpra Borowskiego ${ }^{17}$.

Spośród podanych przez pamiętnikarza nazwisk zesłańców połowa nie figuruje w najpełniejszej kartotece zesłańców postyczniowych, jaka znajduje się w Instytucie Historii PAN w Warszawie. Wymieńmy ich zatem: Abłamowicz (został guwernerem u Zahorskich), Władysław Zaborowski (z Wilna), Borkowski (weterynarz z Litwy), Czenatowski (lekarz), Gintowt (ze Żmudzi), Koczan (mieszczanin), Mizgirł (skrzypek), Nowicki (Ludwik, kompozytor), Pilchowski (hrabia), Rogowski (umarł w Ufie), Słowaczyński, Leon Sulistrowski a także Bronisław Zahorski ${ }^{18}$.

Władysław Zahorski uzupełnia niektóre nazwiska zesłańców informacjami o pochodzeniu społecznym i terytorialnym, o wykonywanym zajęciu, sytuacji

${ }^{15}$ Lokalizacje cytatów pochodzących ze wspomnień Zahorskiego oznaczam w nawiasie podając nr rozdziału i numer karty.

${ }^{16}$ W. Zahorski, $d z$. cyt., rozdz. II, k. 42, 59. Podaje nazwiska: ks. Żuk, kanonik Bojarski i ks. kanonik Augustyn Lipnicki.

${ }^{17}$ W. Zahorski, dz. cyt., rozdz. VII, k. 5.

${ }_{18}$ Nie można wykluczyć błędnego zapisu nazwiska przez Zahorskiego lub mojego odczytu (różne zapisy samogłosek). 
rodzinnej. Nie można jednak na ich podstawie stworzyć zbiorowego portretu socjologicznego, w którym procentowo charakteryzuje się występowanie poszczególnych cech w zbiorowości, bowiem największa jest pozycja „brak danych”, co oznacza, że przewaga liczbowa po stronie osób o określonej cesze (np. zawód, status rodzinny) nie może być podstawą wnioskowania o rzeczywistej ich przewadze w grupie. Pozostaje więc opis mniej lub bardziej jednostkowych sytuacji.

Struktura społeczna zesłańców politycznych w guberni orenburskiej i ufijskiej po powstaniu styczniowym odzwierciedla zróżnicowanie pochodzenia społecznego osób związanych z powstaniem (zarówno osoby z warstw uprzywilejowanych jak i chłopi, mieszczanie, itd.), ale trudno ocenić czy odbija ich proporcje, czy może bardziej politykę karną władz wobec poszczególnych części społeczeństwa i prowincji. Spośród wymienionych 485 zesłańców znajdujących się w $1865 \mathrm{r}$. pod nadzorem policji przeważały osoby pochodzenia szlacheckiego $(67 \%$, wyliczenia Latypowej), pozostali to duchowni, mieszczanie, oficerowie, raznoczyńcy, chłopi ${ }^{19}$. Zesłańcy opisani przez Zahorskiego tworzyli dość jednorodne społecznie środowisko ziemiańsko-szlacheckie i inteligenckie. Tytuły hrabiowskie czterech osób (Aleksander Bisping, Stanisław Mohl, Pilchowski, Władysław Sołtan) i marszałkowski jednej (Aleksandrowicz) ${ }^{20}$ nie pozostawiają wątpliwości co do ich pochodzenia, statusu społecznego i materialnego. Przynajmniej trzy inne osoby przedstawione z nazwiska także należały do ziemiaństwa, pięć było lekarzami (w tym prof. Włodzimierz Dybek, członek Rządu Narodowego), jedna weterynarzem, co to pozostałych 11 osób nie wiemy, jaki był ich status społeczno-zawodowy, choć raczej wywodzili się z rodzin szlacheckich, na co wskazują nazwiska, zajęcia, koneksje rodzinne wskazane w pamiętniku. Niższe warstwy społeczne nie występują $\mathrm{w}$ otoczeniu rodziny pamiętnikarza, wyjątkiem jest mieszczanin Koczan, ale tylko dlatego, że był narzeczonym a następnie mężem towarzyszącej im na wygnaniu kucharki ${ }^{21}$. Inna sprawa, że nie wiemy jak bardzo były one reprezentowane w samej Ufie. Może się więc wydawać, że wygnanie nie demokratyzowało relacji między zesłanymi w takim stopniu, jak można by sądzić na podstawie wyjątkowych okoliczności, a granice integracji zesłanych wyznaczała głównie pozycja przed powstaniem. Z drugiej jednak strony, dająca się odczytać w tekście przyjaźń rodziny Zahorskich z rodziną hrabiego Mohla, jest wyrazem złamania istniejących barier społecznych.

Sytuacja materialna opisanych przez Zahorskiego zesłańców była różna, związana z pozycją rodziny w kraju. Po jednej stronie skali „było niemało biedaków,

${ }^{19}$ W.W. Latypowa, Polskije..., s. 271; taż, Poljaki..., s. 121-126.

${ }^{20}$ Marszałkiem, gub. witebskiej, był także Stanisław Drozdowski, wymieniony przez Zahorskiego jedynie z informacją, że przybył „prawie jednocześnie z nami”.

${ }^{21}$ Do niższych warstw nie należeli też raczej „trzymający się osobno” zesłańcy z dalszych partii, których pamiętnikarz nazywa „szumowinami społecznymi”; przeczą temu informacje o ich kontaktach z innymi zesłańcami. 
nie mających żadnych środków do życia” (II/32), „,wtrąconych prawie w nędzę" (II/53), a po drugiej kilka rodzin, w tym autora wspomnień, które wiodły właściwie normalne, dostatnie życie. Część z nich otrzymywała regularnie pieniądze z domu albo przywiozła jakiś kapitał z sobą, wynajęła domy. Na przykład 21-letni w 1863 r. hr. Bisping „,pędził życie wygodne, zajmował duże mieszkanie, miał liczną służbę, trzymał konie" (II/35), z pewnością nie cierpieli biedy hrabiostwo Mohlowie, czy marszałkostwo Aleksandrowiczowie. Kapitałem, który pomagał ułożyć sobie życie w sferze materialnej, było wykształcenie. Prawo zabraniało zatrudniać skazańców pod nadzorem policyjnym, obawiano się ich wpływu na rosyjskie społeczeństwo, jednak ogromny niedobór ludzi posiadających wykształcenie i kwalifikacje (nauczycieli, lekarzy, ale także przedstawicieli różnych rzemiosł) skłaniał władze do udzielania zgody na podejmowanie pracy $^{22}$. Jak były to liczne przypadki, trudno powiedzieć. We wspomnieniach Zahorskiego właściwie tylko jego ojciec i prof. Dybek, obaj lekarze oraz prowadzący jakiś handel Koczan, występują jako osoby pracujące. Skądinąd wiemy, że wymieniony w pamiętniku kompozytor Nowicki, to Ludwik Nowicki, bardzo zasłużony na Uralu nauczyciel muzyki, dyrygent i kompozytor ${ }^{23}$. Zamożniejsi zesłańcy zatrudniali u siebie rodaków, np. w roli nauczycieli swych dzieci lub po prostu przyjmowali ich do stołu. Zesłanie, które „z dostatku wtrącało w nędzę” uzmysławiało, jak zmienny może być los i kruchy byt materialny. Hr. Władysław Sołtan, o którego statusie materialnym w Ufie nic Zahorski nie pisze, poza tym, że mieszkał w sąsiednim domu, kazał uczyć syna stolarki, przygotowując na trudności (bo „każdy człowiek powinien znać swoje rzemiosło, ponieważ nie wiadomo, co go czeka w życiu", II/33). Nie można wykluczyć, że wspomniane w pamiętniku samobójstwa (hr. Bisping, Leon Sulistrowski) miały związek z drastyczną zmianą sytuacji życiowej.

Także sytuacja rodzinna zesłańców w Ufie była różna. Przynajmniej 9 z wymienionych 24 zesłańców towarzyszył ktoś z rodziny - żona (mowa jest o 7), matka (Gintowt „,z rodziną i staruszką matką") i dzieci (łącznie z dziećmi Zahorskich $-10)^{24}$. Nie widać wyraźnie dużej grupy kobiet, co w odniesieniu do całej kolonii

${ }^{22}$ Również obawiano się złego wpływu polskich dzieci w szkole, jednak minister uznał, że korzyści związane z nauką w rosyjskiej szkole mogą być większe niż niebezpieczeństwo. W.W. Latypowa, Polskije..., s. 275, 272-273.

${ }^{23}$ W.W. Latypowa, Polskije..., s. 273. Podjęcie pracy wymagało poparcia gubernatora i zgody ministra spraw wewnętrznych; Lebiediewa powołuje się na korespondencję między obu władzami, z której wynika, że z braku odpowiednich kadr można było zatrudnić się nawet w urzędzie, ale nie w szkole.

${ }^{24}$ W.W. Latypowa, Poljaki..., s. 124-125. O udziale kobiet wśród zesłanych postyczniowych, także najnowsza literatura zob.: W Caban, L. Michalska-Bracha, Kobiety powstania styczniowego na Syberii. Zesłanki do Usola i Kunguru, [w:] Postawy i aktywność kobiet w czasie powstania styczniowego 1863-1864 (Na tle polskich konspiracji i działalności powstańczej doby zaborowej), pod red. T. Kulak, J. Dufrat, M. Piotrowskiej-Marchewy, Wrocław 2013, s. 163-189. 
zesłańców w Ufie zauważa Latypowa ${ }^{25}$. Z pewnością łatwiej było znieść oddalenie i nieznaną sytuację z rodziną, ale decyzja większości miała prawdopodobnie związek z zamożnością. Najzamożniejsze rodziny tworzyły ważne dla zesłańców tzw. domy familijne. Do listy opisanych już przez badaczy, wspomnienia Zahorskiego dodają trzy: dom hrabiostwa Mohlów, marszałkostwa Aleksandrowiczów oraz rodziców pamiętnikarza ${ }^{26}$. Sytuacja materialna Zahorskich dzięki państwowej posadzie i praktyce lekarskiej ojca była bardzo dobra (m. in. obszerne wynajmowane mieszkanie), pozwalająca otoczyć realną opieką znajdujących się w trudnym położeniu rodaków.

Iluż to wygnańcom - pisze syn - pomagali oni, nie pamiętam obiadu, aby przy naszym stole nie zasiadało paru ubogich rodaków, dla innych rodzice moi wyszukiwali zajęcia. Mieszkali u nich guwerner, staruszek Wł[adysław] Zaborowski i weterynarz Borkowski (II/37).

Zahorski nie pisze o tak podkreślanej w literaturze przedmiotu roli kobiet i tworzenia namiastki domu rodzinnego, kładzie akcent na funkcje opiekuńcze, także w relacjach z władzami. Domy te, według niego, organizowały pierwsze dni po przybyciu, udzielały czasowo lub stale miejsca do mieszkania, przyjmowały do stołu, wyszukiwały płatne zajęcia lub zatrudniały u siebie, świadczyły pomoc finansową, wstawiały się u władz (jak hr. Stanisław Mohl) ${ }^{27}$.

Pamiętnikarz wspomina, że „od czasu do czasu” zbierało się u jego rodziców „dość liczne towarzystwo, wyłącznie polskie”. Koncertowano, korzystając z obecności wśród zesłańców muzyka i kompozytora Nowickiego oraz skrzypka Mizgirła, a ,starsi panowie zasiadali do preferansa lub wista i niekiedy grywano na kilku stolikach" (II/43). Okazją do spotkań zesłańców i przy tym manifestowania swojej tożsamości narodowej były imieniny Bronisława, 18 sierpnia. Ustawiano wówczas $\mathrm{w}$ mieszkaniu na podniesieniu oświetlony transparent $\mathrm{z}$ orłem białym (ciekawe, że bez Pogoni), na pokrytych dywanem stopniach ustawiano

${ }^{25}$ W.W. Latypowa, Polskije..., s. 271.

${ }^{26}$ Zob. np. W. Caban, Dom syberyjski polskich zesłańców politycznych w latach czterdziestych-siedemdziesiatych XIX w., [w:] Dom - spotkanie przestrzeni prywatnej i publicznej na tle przemian cywilizacyjnych XIX i XX w. Zbiór studiów, red. Z. Opacki i D. Płaza-Opacka, Gdańsk 2008, s. 107-119; W. Zahorski, $d z$. cyt.; Gieysztor także wspomina małżeństwo Aleksandrowiczów, nic nie pisząc, by pełnili jakąś rolę w stosunku do zesłańców, natomiast domem familijnym nazywa dom znanego Zahorskiemu Stanisława Drozdowskiego, marszałka gub. witebskiej. J. Gieysztor, $d z$. cyt., s. $102,106$.

${ }^{27}$ „Hrabiostwo Mohlowie - pisze Zahorski - stali się w Ufie opatrznością dla wygnańców, pomiędzy którymi było nie mało biedaków, nie mających żadnych środków do życia. Dom Mohlów był otwarty dla wszystkich potrzebujących pomocy; zawsze ktoś u nich lokował się, zawsze kilku biedaków siadało do ich stołu. Hrabia wyszukiwał dla jednych mieszkanie, dla innych zajęcie, pomagał pieniężnie, wstawiał się do władz". (II/32). Swoją drogą to ciekawe, że zesłaniec polityczny, który na dodatek uniknął kary śmierci, mógł szukać protekcji u władz dla swoich współtowarzyszy. Albo to przykład siły tytułu i ponadnarodowych powiązań arystokracji, albo licencia poetica Zahorskiego. 
w malowniczych pozach dzieci ubrane w stroje narodowe: staropolski, krakowski, chłopa litewskiego ${ }^{28}$. Trzeba jednak wyraźnie zaznaczyć, że to „wyłącznie polskie" towarzystwo nie było raczej, zważywszy na status Zahorskich w Ufie, wyłącznie zesłańcze, choć cytat pochodzi z rozdziału poświęconego zesłańcom, ma raczej charakter skumulowanego $\mathrm{z}$ wspomnieniami o wszystkich latach pobytu z rodzicami na Uralu, gdzie po amnestii w 1867 r. ,zostali nieliczni Polacy, którzy znaleźli tu zarobek lub otrzymali posadę" (VI/177), a do polskiego towarzystwa należeli także przecież licznie wymienieni przez Zahorskiego Polacy pracujący na Uralu.

Dosłownie wspólny dom zorganizowali zesłani do Birska księża, o ile oczywiście Zahorski był dobrze poinformowany. Wszyscy oni mieszkali razem i trzymali wspólną kasę. ,Jeden z nich zakupywał produkty i zarządzał kuchnią, inni również pełnili rozmaite funkcje.”(II/59), wierni z miejscowości, gdzie księża świadczyli usługi duszpasterskie, zaopatrywali ich co jakiś czas w produkty i pieniądze ${ }^{29}$.

Wspólnotę zesłańców współtworzyło również praktykowanie kultu religijnego. Przejawiała się ona nie tylko w obecności w jednym czasie i miejscu największej liczby Polaków, ale też pewnych działaniach przygotowawczych. W Ufie, gdzie nie było kościoła katolickiego, kilka razy do roku przyjeżdżał z Birska na kilka dni ksiądz, by spełnić posługę kapłańską. Wygnańcy zwykle tłumnie wychodzili na spotkanie księdza na przystań i równie tłumnie go żegnali. Na mszę schodzili się do przygotowanej w domu Mohlów lub Zahorskich kaplicy:

\begin{abstract}
Wszyscy byli ubrani odświętnie, a na twarzach malowały się skupienie, powaga i wzruszenie. Msza była śpiewana przy dźwiękach fisharmonii, na której grał Nowicki. Śpiewał chór złożony z pań i panów. Do mszy służyło czterech poważnych wiekiem wygnańców. Pomimo, iż miałem zaledwie lat 7, uroczysty i podniosły nastrój udzielał się i mnie, chociaż nie rozumiałem dlaczego westchnienia, płacz i jęki co chwilę rozlegały się w kaplicy. Pamiętam, iż raz nawet wyniesiono panią, która zemdlała. W godzinach poobiednich odbywała się generalna spowiedź, a nazajutrz rano komunikowano. [...] Te odwiedziny księdza, nabożeństwo, spowiedź stanowiły jakby łącznik z krajem, do którego tęskniono, o którym wciąż myślano i który widziano w marzeniach sennych. Podczas mszy, wyobraźnia przenosiła każdego wygnańca $\mathrm{w}$ jego strony rodzinne, stąd pochodziły płacz, westchnienia i jęki (II/59-60).
\end{abstract}

Opis Zahorskiego potwierdza opinię historyków, że Kościół był namiastką ojczyzny, a zesłańcy w tak podniosłej uroczystości wydawali się być jedną rodziną ${ }^{30}$.

${ }^{28}$ W. Zahorski, $d z$. cyt., rozdz. II, k. 43.

${ }^{29}$ O gospodarstwach samotnych mężczyzn zob. W. Caban, Dom syberyjski..., s. 113-118.

${ }^{30}$ B. Kumor, Kościót i katolicy w cesarstwie rosyjskim (do 1918 roku), [w:] Odrodzenie Kościoła katolickiego w bytym ZSRR, red. E. Walewander, Lublin 1993, s. 30. 
Obraz środowiska zesłańczego wcale jednak nie jest u Zahorskiego tak jednobarwny. Z jednej strony mamy zesłańczą, wspierającą się wspólnotę opisaną po latach w ciepłych barwach:

Gdy dziś przenoszę się myślą w owe czasy, dziwię się skąd się brał ów humor, owa pogoda i wesołość. Wszak w Ufie byli wygnańcy, oderwani od ziemi rodzinnej, od matek, żon, dzieci, narzeczonych, od wszystkiego co kochali i z czym się zrośli. Byli to ludzie co wiele przecierpieli, którzy z dostatku zostali wtrąceni prawie w nędzę i którzy nie wiedzieli co ich jeszcze czeka w przyszłości. A jednak pomimo to wszystko jakaż cechowała ich pogoda ducha, jaka wiara w lepszą przyszłość, jakie poddanie się losowi bez skarg i wyrzekań. Przypuszczam, że takimi czyniło ich czyste sumienie i poczucie spełnionego względem ojczyzny obowiązku. Wygnańcy tworzyli na obczyźnie jakby jedną rodzinę, wzajemnie się serdecznie podtrzymywali, strapionych pocieszali, uboższych wspomagali. Każdym listem, każdą wiadomością z kraju dzielono się jak z rodzeństwem. Mam na myśli naturalnie tych lepszych (II/53).

Nie negując, ani nie podważając prawdziwości tego obrazu, znajdującego potwierdzenie $\mathrm{w}$ wielu innych zesłańczych wspomnieniach, a nawet doceniając mądrość tłumaczenia opisanej postawy, trzeba uznać za być może jeszcze bardziej prawdziwy, związany z inną stroną natury ludzkiej, inny opis Zahorskiego:

Z następnymi partiami wygnańców zaczęli napływać rozmaite nie wysokiej wartości indy-
widua. Dziś nie moge zrozumieć, za co oni zostali deportowani. Sami oni wydawali [s]
siebie za bohaterów, opowiadali dziwy o swych czynach, odwadze, poświęceniu się i cier-
pieniach i na razie wierzono tym baśniom. Wkrótce jednak okazało się, że byli to hultaje,
wydrwigrosze, warchoły. Oni to wnieśli niezgodę pomiędzy wygnańców, intrygowali, roz-
siewali plotki i oszczerstwa, niejednych poróżnili i nawet doprowadzili do pojedynku. Nie
potrzebuję mówić, jak ci panowie kompromitowali imię polskie wobec Rosjan. [I dalej:]
Żaden prawie z wybitnych i zacnych wygnańców nie uniknął oszczerstw ze strony tych
niegodziwców. Najbardziej wycierpiał hr. Mohl (II/32).

Czy intrygi, plotki, oszczerstwa, potwarze i szkalowanie, spory i konflikty kończące się nawet pojedynkami i samosądami miały związek z powstaniem, czy dotyczyły sytuacji i zachowania na zesłaniu, Zahorski nie pisze. Promyk światła rzuca zdarzenie dotyczące pierwszego nauczyciela pamiętnikarza („kochaliśmy się z nim ogromnie”), Gorzkowskiego, który obraził jednego z „nicponiów”.

Ten do współki ze swymi godnymi towarzyszami złożyli zaoczny sąd nad Gorzkowskim, poczym jeden z nich zaprosił go do siebie na herbatę. Gdy Gorzkowski, nie podejrzewając podstępu przyjął zaproszenie, zastał tam sześciu wygnańców, którzy oświadczyli, iż za obrazę ich przyjaciela skazali go na rózgi, poczym rzucili się na bezbronnego, rozebrali do naga i zawinąwszy w mokre prześcieradło, aby nie zostało na ciele śladów od rózeg, siekli biedaka bez litości (II/38-39).

Jak w każdej większej społeczności, tak i wśród zesłańców, byli ludzie o różnych cechach, które dramatyczna, ekstremalna sytuacja dość jednak zamkniętego 
środowiska jeszcze wyostrzała, podobnie jak zwiększała wyczulenie na osobisty honor. Nie wiemy co takiego zrobił Gorzkowski, ale zesłańcy, „nie wysokiej wartości indywidua", posługiwali się swoim kodeksem norm i mieli swój wymiar sprawiedliwości (sąd, wyrok, kara), ukrywany przed zewnętrznym światem. Występki nie dotyczyły jedynie zesłańców, skoro Zahorski zarzucał tej grupie psucie opinii wśród Rosjan, do czego jeszcze wrócimy w dalszej części artykułu.

Sam Zahorski nie szczędził niektórym z wygnańców z pierwszych partii ośmieszających lub kompromitujących ich cech, ale były one niegroźne dla współtowarzyszy ${ }^{31}$. Pamiętnikarz lubi wytykać słabości, bywa złośliwy, stara się opowiadać anegdoty. Niekiedy te złośliwe opowieści wnoszą do wiedzy o życiu codziennym cenne dane. Na przykład przy okazji anegdoty o łatwowierności zesłańca Słowaczyńskiego „,chudego jak szkielet, z jasną kozią bródką”, dowiadujemy się, że do Ufy docierała „Gazeta Polska" ${ }^{2}$.

Informacje o konkretnych osobach bardziej przekonują co do ich prawdziwości, niż opisy i opinie o całej zbiorowości, które zawsze rodzą wątpliwości, ile jest w nich własnych/rodzinnych wspomnień, ile zaś wpisania się w mit zsyłki, przejęcia dominującej [?] narracji w innych zesłańczych pamiętnikach, których sporo ukazało się do I wojny światowej. Dopóki jednak nie przeprowadzi się analizy porównawczej tekstów, poruszać się będziemy w sferze pytań i niepewności.

W partiach pamiętnika z późniejszych lat zesłańcy pojawiają się sporadycznie $^{33}$. Wspomina o dwóch osobiście poznanych osobach, które odbywały karę na Syberii, a w wyniku jej złagodzenia, pozwolono im zamieszkać w europejskiej części Rosji. Zdzisław Mitkiewicz po odbytej katordze osiadł w Jekaterynburgu i był dyrektorem towarzystwa ubezpieczeń [!] (ale też był mężem rosyjskiej arystokratki), a lekarz Wyszyński przedstawia typ byłego powstańca i katorżnika, który stopniowo zbliżał się, w czasie i przestrzeni, do kraju - po uwolnieniu z katorgi pozwolono mu osiedlić się w Irkucku, następnie przeniósł się do Jekaterynburga, gdzie prowadził praktykę lekarską, odkrył uzdrowiskowe właściwości wód w miejscowości Kurje, przez kilka lat był tam lekarzem zdrojowym, by w końcu przenieść się do Warszawy ${ }^{34}$.

${ }^{31}$ Wypomina głupotę i cwaniactwo mieszczaninowi Koczanowi, naiwność, głupotę hr. Pilchowskiemu, o staruszku Władysławie Zaborowskim pisze, że był niemożliwie skąpy („Sam prał sobie bieliznę, cerował skarpetki, łatał ubranie”), a o weterynarzu Borkowskim, że był to ,poczciwy człowieczyna, ale niezbyt inteligentny”. Szkody innym wyrządził jedynie przygarnięty przez Zahorskich wygnaniec, który za utrzymanie miał uczyć starszego brata Władysława, a znęcał się nad chłopcem.

${ }^{32}$ W. Zahorski, dz. cyt., rozdz. II, k. 34.

${ }^{33}$ Prawdopodobnie większość zesłanych po amnestii z 1867 i 1872 r. powróciła do domu, $\mathrm{z}$ innych zdjęto nadzór i określono warunki osiedlania się $\mathrm{w}$ wewnętrznych guberniach Rosji. W 1872 r. pozostawało jeszcze 140 polskich zesłańców pod nadzorem, przy czym wśród nich mogły być osoby przybyłe z Syberii (prawo pobytu poza stolicami i guberniami zachodni. W.W. Latypowa, Polskije..., s. 273-274.

${ }^{34}$ W. Zahorski, dz. cyt., rozdz. XIV, k. 265; rozdz. XV, k. 44. 
Jedno z ważniejszych pytań odnośnie zesłańców w Ufie - czy wspólnota kary przełożyła się na powstanie wspólnoty zesłańców znajduje we wspomnieniach Zahorskiego odpowiedź pozytywną. Sytuacja materialna i rodzinna zesłańców, różne możliwości adaptacji w nowych warunkach, w połączeniu z pewną wspólnotą losu wygnania prowadziły do powstawania relacji powiązań i zależności nastawionych na bycie razem, na świadczenie i otrzymywanie pomocy, aby przetrwać. Obok osobistych kontaktów towarzyskich istniały „instytucje” - domy familijne, Kościół.

Osobne zagadnienie badawcze to relacje między zesłańcami a miejscową ludnością, a zwłaszcza Rosjanami. W pamiętniku przeważa narracja o ich przyjaznej i towarzyskiej koegzystencji, ale nie bez pewnej dynamiki zmian w stosunku Rosjan do przybyszy z ziem polskich. Po początkowym okresie nieufności, Rosjanie nie tylko zaczęli okazywać Polakom sympatię, ale nawet im pomagać. Jeśli Zahorski trafnie odzwierciedla sytuację, to najszybciej nastąpiło to w środowisku gubernialnej elity:

\begin{abstract}
Na razie Polacy mało się łączyli z Rosjanami - pisze - ci ostatni jednak, szczególnie obywatelstwo okazywali Polakom wiele życzliwości i sympatii, pierwsi składali wizyty, zapraszali do siebie na obiady i bale. Toteż nawiązały się z czasem stosunki towarzyskie, a nawet niekiedy przyjaźnie. Za obywatelstwem poszli wyżsi urzędnicy, którzy, o ile to było w ich mocy, starali się ulżyć doli wygnańców, i w każdym razie nigdy ich nie szykanowali i nie uciskali (II/44).
\end{abstract}

Opisana sytuacja mogła być w pierwszej kolejności doświadczeniem rodziny Zahorskich i rodzin arystokratycznych. Szybkiemu nawiązaniu znajomości, zwłaszcza w karnawale, gdy do Ufy zjeżdżali obywatele ziemscy, sprzyjało wiele czynników: charakter kary zesłańców (zamieszkanie), ich ziemiańskie pochodzenie, wykształcenie, dochody umożliwiające uczestniczenie w rozrywkach na równych prawach, nie bez znaczenia mogła mieć również pamięć o polskim pochodzeniu części ziemiaństwa ufijskiego, potomków szlachty smoleńskiej z XVII w. ${ }^{35}$ Kontakty prywatne nie były zabronione. Obyci w świecie, umiejący tańczyć, grać na fortepianie, znający języki, stanowili bardzo atrakcyjne towarzystwo dla rodzin miejscowego ziemiaństwa i urzędników ${ }^{36}$. Dla pracujących w Ufie (jak i w pozostałych miejscach zamieszkania Zahorskiego na Uralu) Polaków, zwłaszcza zajmujących podobną pozycję co ojciec pamiętnikarza, drzwi domów elit społeczno-gospodarczych były otwarte, przyjmowano Polaków do klubu

${ }^{35}$ W. Zahorski, $d z$. cyt., rozdz. VI, k. 175.

${ }^{36} \mathrm{O}$ zażyłości zesłańców z miejscową elitą pisze Latypową, jako dowód przytaczając za wspomnieniami Zahorskiego, propozycję, by jego ojciec przepisał się ze szlachty wileńskiej do ufijskiej oraz historię obrażenia w klubie szlacheckim lekarza Polaka Henryka Karasińskiego i reakcję Rosjan - wykluczenia winowajcy z klubu. Oba przykłady są nietrafione, bo nie dotyczą zesłańców, którzy nie mieli prawa wstępu do klubu szlacheckiego i innych organizacji. Z powodu pozycji obu Polaków nie bardzo nadają się też do uogólniania. W.W. Latypowa, Polskije..., s. 278-279. 
szlacheckiego, nawiązywały się znajomości, a niektóre przeradzały w przyjaźnie. Bywano i bawiono się wspólnie w rosyjskich domach i instytucjach publicznych (obiady, bale, maskarady, szlichtady, teatr itp.) ${ }^{37}$. Trudno jednak na podstawie tekstu powiedzieć, że dotyczyło to zarówno zesłańców jak i dobrowolnych migrantów. Zahorscy, ojciec i syn, obracali się w obu środowiskach; nie sposób odróżnić o kim pisze pamiętnikarz. Opowieść Władysława Zahorskiego o swojej rodzinie, która żyła w kontakcie z zesłańcami i jednocześnie bez problemu funkcjonowała w świecie rosyjskiej gubernialnej elity (pamiętnikarz zamieszcza długie opisy uczestnictwa w życiu towarzyskim Rosjan w Ufie i Permie, przyjaźń z rodziną gubernatora), rzucałaby nowe światło na relacje władze - zesłańcy, gdyby nie fakt, że nie da się oddzielić w tekście statusu uczestników ze strony polskiej. Relacje zesłańców z miejscową elitą urzędniczo-obywatelską, ich meandry, wymagają dalszych badań.

Miejscowe stosunki Rosjan z zesłańcami zależały od polityki rządu, lokalnych władz, obawiających się wpływu nieprawomyślnych i buntowniczych Polaków na miejscową ludność ${ }^{38}$, od osobowości i poglądów zarządców guberni. $\mathrm{Z}$ pewnością nie były tak idylliczne jak to przedstawia Zahorski. Obserwacja przybyłego do Ufy z Petersburga oficera sztabu korpusu żandarmów była zupełnie inna. W styczniu 1867 r. informował swego zwierzchnika, że „zesłani Polacy traktowani są z wielką niechęcią przez całe społeczeństwo", ale przyznawał, że są rosyjskie domy, „w których czasami pojawiają się Polacy"39.

Jako negatywny, oceniał też stosunek administracji i ludności do Polaków w gub. orenburskiej po 1863 r. przebywający tam na zesłaniu Tadeusz Korzon ${ }^{40}$. Zahorski natomiast odnotowuje wyraźną zmianę w stosunku do Polaków z chwilą przybycia (1875) nowego gubernatora, Lewszyna, byłego współpracownika Murawiewa na Litwie, rusyfikatora, którego niechęć do Polaków stała się powodem przeniesienia się Zahorskich do Permu.

Również niższe warstwy społeczne, według pamiętnikarza, przekonały się dość szybko do Polaków, chociaż nastąpiło to po okresie nieufności a nawet obaw

${ }^{37}$ Partie wspomnień dotyczące pobytu w Ufie, Permie, Jekaterynburgu i Czelabińsku pełne są opisów życia towarzyskiego Polaków i Rosjan. Każde z miast było inne pod względem struktury elity, co decydowało w pewnym stopniu o skali i charakterze tych kontaktów. Obywatelsko-urzędnicza Ufa, zwłaszcza zimą, gdy zjeżdżali do stolicy guberni ziemianie, bardziej sprzyjała kontaktom, niż urzędniczy Perm, gdzie ,nie było tej swobody”, czy kupiecko-przemysłowy Jekaterynburg oraz bardzo prowincjonalny, mały Czelabińsk z „nieokrzesanym kupiectwem”, gdzie już dorosły Zahorski z żoną miał bardzo ograniczony krąg znajomych i gdzie też Polaków było niewielu.

${ }^{38}$ Np. pogłoski o przygotowywaniu przez Polaków i Baszkirów powstania w pow. czelabińskim. W.W. Latypowa, Polskije..., s. 278.

39 J.Z. Pająk, J. Szczepański, Problemy identyfikacji i interpretacji źródet pamiętnikarskich z Ziem Zabranych w XIX w. (casus Jana Bispinga i Jana Witorta), [w:] Polskie dziewiętnastowieczne pamiętniki $i$ listy z Ziem Zabranych - rola $i$ miejsce $w$ badaniach historycznych, red. W. Caban i L. Michalska-Bracha, Warszawa 2017, s. 184.

${ }^{40}$ T. Korzon, $d z$. cyt., s. 110-120. 
związanych z falą pożarów, jaka przetoczyła się we wschodniej Rosji latem 1864 r. i, o które obwiniano Polaków ${ }^{41}$.

Jednak przekonawszy się o niewinności Polaków, poznawszy ich i zrozumiawszy, że nie są oni zbrodniarzami, że walczyli i cierpią za ojczyznę i wiarę, zmienili względem nich swoje postępowanie i jako o łaskę prosili wygnańców, by lokowali się w ich domach, ustępowali z komornego i świadczyli liczne drobne usługi (II/36).

Pamiętnikarz uderza w wysokie tony i zapewne przesadza też $\mathrm{z}$ objawami rosyjskiej życzliwości, ale w innym miejscu pozytywne nastawienie Rosjan tłumaczy przede wszystkim rolą i postawą samych Polaków - „ludzi zacnych, prawych i wykształconych”, którzy „w znacznej mierze wpłynęli na wyrobienie wśród ludności ufijskiej szacunku i sympatii względem Polaków.” Jako przykład podaje prof. Dybka („,był jednym z tych ludzi, co będąc na obczyźnie postępowaniem swoim zmuszają obcokrajowców do szanowania Polaków i podtrzymują honor imienia polskiego”, II/35) oraz - „z dumą synowską" - swoich rodziców, „którzy zarówno wśród współtowarzyszów wygnania jak i wśród Rosjan cieszyli się zupełnie zasłużonym szacunkiem i uznaniem" (II/37). Mieszkańcy Ufy poznawali zesłańców lepiej, gdy ci mogli już pracować:

w 10 lat po powstaniu, [...] pozostali Polacy adwokaci, lekarze, inżynierowie, technicy byli ludzie godni i cieszyli się zasłużonym szacunkiem. Dość powiedzieć, że w Rosji kasjerami w bankach rządowych i wielu prywatnych lub akcyjnych są przeważnie Polacy, a kupcy bardzo często pożyczają Polakom pieniądze na słowo i nie chcą brać od nich pokwitowań (VI/176).

Prowadzi to do niezmiernie ważnej kwestii - roli, jaką polska kolonia, w tym zesłańcy, odegrała na Uralu. Historycy rosyjscy badający znaczenie różnych grup narodowych w tym regionie Rosji, Zauralu (obok Rosjan i Polaków, ludów miejscowych, także Niemcy i inni Europejczycy), nie mają wątpliwości, że wkład Polaków w rozwój kultury i gospodarki na Uralu w ciągu XIX w. był nieproporcjonalnie duży w stosunku do ich liczby, co wynikało ze stosunkowo dużego udziału ludzi posiadających kwalifikacje i wykształcenie ${ }^{42}$. W jakimś zakresie był to także wkład zesłańców postyczniowych ${ }^{43}$.

${ }^{41}$ „Stosunek miejscowej ludności względem wygnańców był życzliwy. Na razie pospólstwo ufijskie myślało, że są to zwykli zbrodniarze - kryminaliści, a że w tym czasie zdarzyło się w Ufie jeden po drugim kilka pożarów, ktoś puścił pogłoskę, że to podpalają Polacy, toteż lud zajął względem tych ostatnich wrogie stanowisko". (II/36)

${ }^{42}$ W.W. Latypowa, Poljaki..., s. 126-147; Poljaki w Piermskom..., s. 7; Zahorski wymienia byłych zesłańców - lekarzy, inżynierów, bankierów, a obok tego wielu przedstawicieli innych zawodów w administracji, fabrykach itd. przybyłych z ziem dawnego państwa polsko-litewskiego, zwłaszcza z guberni zachodnich.

${ }^{43}$ Charakteryzując stosunki w Czelabińsku (gub. orenburska) pisze: „Dopiero po r. 1863 Polacy wygnańcy zaczęli wnosić tu kulturę, uczyli dzieci różnych przedmiotów, obcych języków. Na ich żądanie sprowadzono do Czelabińska pierwszy fortepian, który wywołał prawdziwą sensację” (XIX). 
Zahorski odnotował zmianę w nastawieniu Rosjan do Polaków za panowania Aleksandra III, ale jest to już późniejsza wiedza, nie zaś nabyta podczas mieszkania w Rosji (od połowy lat 80 . w Czelabińsku) ${ }^{44}$.

I na koniec zadajmy pytanie czy zesłańcy dążyli do kontaktów z Rosjanami, jakie były granice „fraternizacji” z, bądź co bądź, przedstawicielami zaborców? Dalszą konsekwencją pytania jest problem asymilacji Polaków w imperium. Nieco światła na to zagadnienie rzuca niewielki fragment wspomnień poświęcony historii zesłańca Aleksandra hr. Bispinga. Warto przytoczyć go w całości:

Smutną po sobie pamięć pozostawił hr. Bisping z grodzieńskiego. Ten młody jeszcze i bardzo zamożny światowiec, przybywszy do Ufy na wygnanie, pędził życie wygodne, zajmował duże mieszkanie, miał liczną służbę, trzymał konie. Hr. Bisping zaczął bywać w domach wyższych urzędników Rosjan, międz y innymi u gubernatora Aksakowa, gdzie był mile widziany, jako salonowiec mówiący płynnie kilku obcymi językami, wcale dobrze grający na fortepianie i doskonały tancerz. Bisping zakochał się i oświadczył córce Aksakowa, która otrzymała staranne wychowanie, była miłą, przystojną i odznaczała się dobrocią i prawością charakteru. Wraz potem odbyły się zaręczyny, poczym gubernator wyjednał u cara zupełne ułaskawienie przyszłego zięcia. Pewnego dnia Bisping, przyjechawszy do Aksakowa, oświadczył mu, że wchodząc do jego rodziny uważał za stosowne przejść na prawosławie i właśnie dziś to uczynił. Gubernator nic na to nie odrzekł, tylko zawoławszy lokaja kazał mu poprosić córkę. Ta, gdy Bisping oznajmił jej radośną, jak sądził, nowinę, spojrzała nań z najwyższą pogardą i nie rzekłszy ani słowa, zdjęła z palca pierścionek zaręczynowy, położyła go na stole przed zbitym z tropu narzeczonym, wyszła z salonu i dopiero w przyległym pokoju upadła zemdlona. Pan Aksakow pożegnał niedoszłego zięcia nie podając mu ręki. Drzwi nie tylko polskich, ale i niektórych rosyjskich domów zamknęły się przed renegatem, który niebawem opuścił Ufę i udał się w grodzieńskie, a gdy i tam brat i ciotka nie zechcieli go widzieć, w Grodnie w wannie przeciął sobie na rękach arterie i umarł (II/35-36).

Ostatnio opublikowany artykuł Jana Pająka i Józefa Szymańskiego oraz zamieszczone $\mathrm{w}$ nim aneksy pism urzędowych $\mathrm{w}$ sprawie Bispinga otwierają nowe możliwości nie tylko weryfikacji wiedzy Zahorskiego, ale i interpretacji jego pamięci i narracji o ordynacie na Massalanach (gub. grodzieńska) zesłanym w 1863 r. do Ufy za (rzekomą?) pomoc powstańcom ${ }^{45}$.

W przedstawionych przez Zahorskiego kolejnych zbliżeniach hrabiego z Rosjanami (towarzyskie kontakty z urzędnikami, zaręczyny z Rosjanką i córką gubernatora, przejście na prawosławie), dopiero porzucenie własnej wiary, na dodatek z nadgorliwości, bez potrzeby, nikt przecież od Bispinga tego nie żądał,

${ }^{44}$ „Słyszałem, że potem (po 1880) na niekorzyść naszą zmieniły się [stosunki]. Nikczemne rządy Aleksandra III, rosyjska prasa gadzinowa, co „Nowoje wremia” Suworina, „Grażdanin” ks. Mieszczerskiego i „Swiet” Komarowa, szkalując Polaków i pomawiając ich o rozmaite zbrodnie zasiało w Rosjanach względem nas ziarna nieufności i niechęci. Za czasów jednak mojej młodości było inaczej". (VI/177).

${ }^{45}$ J.Z. Pająk, J. Szczepański, dz. cyt. (aneksy s. 185-186). W świetle tych pism Gieysztor i Zahorski nie znali dobrze faktów, ich prostowanie nie należy jednak do tematu niniejszego artykułu. 
ani nie oczekiwał, skazało młodego hrabiego na potępienie, ostracyzm towarzyski ze strony współwygnańców i miano renegata.

Inaczej o sprawie pisał w swych pamiętnikach, prawdopodobnie znanych Zahorskiemu, Jakub Gieysztor, który w 1863 r. przebywał kilka miesięcy na zesłaniu w Ufie i z racji pewnych koneksji sprawował, jak można się domyślać, opiekę nad wówczas ok. 21-letnim Bispingiem:

wydał mi się dobrym, choć pustym chłopcem. Po moim wyjeździe [?], kiedy Bisping zaczął uczęszczać do domów rosyjskich, jedni stanowczo go potępiali, inni chcieli wpłynąć perswazją; potworzyły się partie, zginęła zgoda. Bisping brnął dalej i ożenił się z córką gubernatora, przyjął prawosławie, w końcu odebrał sobie życie ${ }^{46}$.

A więc już samo bywanie Bispinga w domach rosyjskich wywołało u wygnańców potępienie, a różnice między zesłańcami, jak postąpić z młodzieńcem, przyczyniły się nawet do rozbicia wspólnoty zesłańczej ${ }^{47}$. Zahorski, w porównaniu do Gieysztora, przesuwał więc znacznie dalej granicę dopuszczalnego kompromisu w stosunkach Polaków z Rosjanami, nie ma wątpliwości, że jest nią porzucenie wiary. Jego narracja o Bispingu zdaje się potwierdzać tezę o jednoznacznym potępieniu przez polską opinię publiczną dobrowolnych aktów konwersji katolików na prawosławie i wykluczaniu takich osób ze wspólnoty narodowej. Na marginesie już dodajmy, że nie mogło być to odbierane tak samo w całym społeczeństwie o różnym przecież stopniu poczucia własnej tożsamości, chociaż związek $\mathrm{z}$ wyznawaną religią wydaje się najsilniejszą więzią. Walentyna Latypowa pisze o szybkiej asymilacji zesłańców w guberni orenburskiej, zapewne z warstw niższych, czego dowodem są ożenki z Rosjankami często połączone z przyjęciem prawosławia (np. w pow. czelabińskim w 1868 r. 10 małżeństw z przyjęciem prawosławia, $21 \mathrm{bez})^{48}$.

Warto zwrócić uwagę na perspektywę, z jakiej Zahorski (ale z pewnością nie wszyscy zesłańcy) ocenia Bispinga. Według pamiętnikarza, młodzieniec pozostawił „smutną pamięć”, gdyż - w przeciwieństwie do tych, jak prof. Dybek, Bronisław Zahorski, i sam autor pamiętnika, którzy „będąc na obczyźnie postępowaniem swoim zmuszają obcokrajowców do szanowania Polaków i podtrzymują honor imienia polskiego" (II/35) - skompromitował się w oczach Rosjan. A stracił ich szacunek i swój honor porzucając własną wiarę - prawosławna narzeczona zerwała zaręczyny, a Rosjanie zamknęli przed nim swoje domy. Zapewne Zahorski znał taką właśnie wersję wydarzeń, ale istotna jest wymowa tak skonstru-

\footnotetext{
${ }^{46}$ J. Gieysztor, $d z$. cyt., s. 104.

${ }^{47}$ Autorzy wspomnianego artykułu przypisują wypowiedzi pamiętnikarza ,"patriotyczny dydaktyzm”, w którym samobójstwo Bispinga „to logiczna konsekwencja zdarzeń”, można dodać - kara za zażyłe kontakty z Rosjanami, małżeństwo z Rosjanką oraz porzucenie swojej wiary. J.Z. Pająk, J. Szczepański, dz. cyt., s. 179.
}

${ }^{48}$ W.W. Latypowa, Poljaki..., s. 147; taż, Polskije..., s. 277-278. 
owanej opowieści. Pisząc o potępieniu młodego hrabiego przez Rosjan (którzy powinni raczej przyklasnąć takiej decyzji) Zahorski przenosi swą ocenę w wymiar wartości etycznych, ale nie narodowej homogenicznej tożsamościowo wspólnoty znanych mu zesłańców a ponadnarodowej wspólnoty ludzi honoru.

Podobny wniosek wypływa z opowiadania o niejakim Sobolewskim, byłym powstańcu z Litwy, który pracował jako zarządca wielkiej gorzelni braci Pokrowskich w Czelabińsku. Zahorski, podejrzewając, że w czasie powstania odegrał niechlubną rolę (obrabował rannego kolegę i pozostawił go w lesie), opowiedział głośno tę historię na przyjęciu u Pokrowskich, w obecności Sobolewskiego:

Gdy wzburzony własnymi słowy skończyłem opowiadanie, powstał Pokrowski i odezwał się w te słowa:

Panowie, po tym, cośmy od doktora usłyszeli i czemu p. Sobolewski nie śmie zaprzeczyć, znajduję, że nie ma dla niego miejsca między nami i dlatego proszę go, by niezwłocznie opuścił [nas?]. Poza tym, nie mogę ufać człowiekowi, który był zdolny popełnić tak ohydny czyn, jak to pan zrobił i dlatego wymawiam panu posadę (XIX/264-265).

Pozostawiam problem stopnia prawdopodobieństwa przebiegu całej sceny i słów, które tam padły. Wymowa tej opowieści kieruje nas znowu w stronę ocen pamiętnikarza. I nie tyle chodzi o morał, iż nie ucieknie się przed sprawiedliwością, ale o fakt, że zachowanie Sobolewskiego potępia i do tego karę wymierza - Rosjanin. Czy Zahorskiemu chodziło o podkreślenie skali wykroczenia nieakceptowanego przez uczciwych Polaków? Jeśli nawet, to nie tylko szło mu o rachunki wewnątrz narodowej wspólnoty.

Zahorski nie jest w swych wspomnieniach antyrosyjski, jak to zdarza się pamiętnikarzom doświadczonym zsyłką, którzy jeśli piszą dobrze o Rosjaninie to na zasadzie podkreślenia jego wyjątkowości. Nasz autor, ulega funkcjonującym mitom, ale też pisze niezależnie od nich i wbrew nim, zgodnie zapewne ze swoim doświadczeniem. Charakterystycznie Zahorski używa etnonimu "Moskale” i „Rosjanie”. W wileńskich partiach pamiętnika, gdy mowa jest o zaborcach, rusyfikatorach, czy o powstaniu, stosuje wyraźnie pejoratywnie nacechowane na początku XX w. określenie „Moskale”49. Gdy opisuje swoje życie w Moskwie i na Uralu zawsze pisze o „Rosjanach”. Problem ten wykracza poza temat zesłańczy, ale pomaga $\mathrm{w}$ zrozumieniu postawy pamiętnikarza, przedstawiającego się jako syna zesłańca.

Sądzę, że Zahorski oceniał i opisywał przeszłość z perspektywy byłego „,argonauty". Pisząc, miał za sobą doświadczenie długiego pobytu w Rosji, który był dla jego rodziny pozytywny, wiązał się z jej zamożnością, spokojnym życiem

${ }^{49}$ Zahorski pisze już w XX w., kiedy utrwaliło się pejoratywne zabarwienie tego określenia, które w pierwszej połowie XIX w. takiej wartości jeszcze nie miało. Zob. na ten temat: A. Niewiara, Moskwicin-Moskal-Rosjanin w dokumentach prywatnych. Portret, Łódź 2006. 
i zakończył dobrowolnym powrotem w rodzinne strony. Wynikał, poza pierwszym krokiem, ze świadomego wyboru, jakiego dokonywało wielu jego ziomków. Zahorscy należeli bowiem do tysięcy polskich inteligentów, którzy dobrowolnie zostali po studiach w Rosji, albo udali się tam dla kariery, lepiej płatnej pracy, czy też - zważywszy na bardzo ograniczony rynek pracy wykwalifikowanej w kraju rodzinnym - dla pracy w ogóle. Próg tolerancji dla kontaktów z narodem zaborcy już z tego powodu był większy u Zahorskiego. Miarą patriotyzmu, zachowania polskiej tożsamości było dla Zahorskiego zachowanie języka ojczystego, kultury i wiary oraz uczciwość zawodowa i osobista, bo, jak pisze, na obczyźnie reprezentuje się nie tylko siebie:

Ojciec często mi powtarzał, że Polak, szczególnie na obczyźnie powinien być bez zarzutu, ponieważ każda plama, każdy cień, który pada na niego stają się krzywdą wyrządzoną Ojczyźnie, bo cudzoziemcy sądzą o wszystkich Polakach po tych, z którymi się spotykają. Jakże często niestety sądzą o nas po wyrzutkach społeczeństwa! Te słowa ojca głęboko mi w duszę zapadły i były mi drogowskazem w całym następnym życiu. Zawsze starałem się postępować tak, aby nie narazić na szwank imienia polskiego (VI/175).

Uwaga poświęcona w pamiętniku życiu zesłańców w Ufie, pełni bardzo istotną dla pamiętnikarza rolę - wpisuje rodzinę Zahorskich w martyrologię pokolenia swych rodziców, które przyczyniło się do odzyskania niepodległości, w żywą jeszcze narrację historyczną Polaków o powstaniu styczniowym. Zahorski pisząc o związkach rodziców i dziadków z powstaniem, o patriotycznym wychowaniu od najwcześniejszego dzieciństwa przez matkę, o przymusowej deportacji rodziny w 1863 r., a później o dbałości o znajomość języka polskiego i kontakt z literaturą polską w Ufie i Permie, wydaje swojej rodzinie świadectwo patriotyzmu i zaangażowania w sprawy narodowe ${ }^{50}$. Jak w każdym przypadku, gdy mamy tylko jedno źródło informacji, tak i w tym należy ostrożnie podchodzić do jego treści. Znacznie bardziej wiarygodnie w tych wspomnieniach brzmi opowieść o losie inteligenckiej rodziny Zahorskich z ziem zabranych, która podejmuje w Rosji pracę, czego Zahorscy w obu pokoleniach są bardzo dobrym przykładem, niż o losie rodziny zesłańczej. Tak czy inaczej oba te wcielenia należały do XIX-wiecznych losów Polaków na Wschodzie.

50 J. Sikorska-Kulesza, Dzieciństwo i młodość a tożsamość narodowa. Wspomnienia Władysława Zahorskiego, „Rocznik Stowarzyszenia Naukowców Polaków Litwy” 2011/2012, t. 10/11, s. 6-26. 


\title{
Jolanta Sikorska-Kulesza \\ POLES IN THE URAL IN THE 60S-80S OF XIX ${ }^{\text {TH }}$ CENTURY IN THE LIGHT OF THE MEMORIES OF WLADYSLAW ZAHORSKI
}

\begin{abstract}
The article is based on a fragment of the diary of Władysław Zahorski, still in the manuscript, I entitled "My memories" and rich literature on the subject. It was written down years later, therefore it should be analyzed with great sensitivity and it should be careful to formulate conclusions. The author of the diary was a well-known Vilnius doctor, cultural and social activist and the author of many works on the history and monuments of Vilnius. The article deals with the problems of exiles in Ufa, observed from the position of a child from the intelligentsia family from western Krai. The author came from a family, whose social position and material status were definitely better than those Poles who were subjected to forced exile in post-January realities. In the diary it can be found the unknown and valuable information, that complements the current state of knowledge about the life of exiles of this part of Siberia. In addition, it creates a cognitive perspective concerning the exiles in the consciousness of a generation of insurgents' children in 1863, to which Władysław Zahorski belonged.
\end{abstract}

Słowa kluczowe: Władysław Zahorski, pamiętnik, zesłańcy, Syberia, Ufa

Keywords: Władysław Zahorski, diary, exiles, Siberia, Ufa

\section{BIBLIOGRAFIA}

\section{Źródła:}

Biblioteka Narodowa w Warszawie

Zahorski W., „Moje wspomnienia”, t. I-IV, rkps II. 10.455.

Archiwum Władysława Zahorskiego, „Dokumenty osobiste Bronisława Zahorskiego i jego żony Marii z Jawłowskich”, rkps IV 10.451, mf. 30866-30875 (formularnyj spisok), 30863.

Korzon T, Mój pamiętnik przedhistoryczny, Kraków 1912.

Pamiętniki Jakuba Gieysztora z lat 1857-1865, t. 2, Wilno 1913.

\section{Opracowania:}

Caban W., Dom syberyjski polskich zesłańców politycznych $w$ latach czterdziestych-siedemdziesiatych XIX $w$., [w:] Dom - spotkanie przestrzeni prywatnej i publicznej na tle przemian cywilizacyjnych XIX i XX w. Zbiór studiów, red. Z. Opacki i D. Płaza-Opacka, Gdańsk 2008, s. 107-119.

Caban W., Zsyłka Polaków na Syberię w XIX wieku. Przegląd publikacji polskich i rosyjskich/radzieckich, „Przegląd Historyczny" 2014, t. 105, z. 4, s. 99-123.

Caban W., Michalska-Bracha L., Kobiety powstania styczniowego na Syberii. Zesłanki do Usola i Kunguru, [w:] Postawy i aktywność kobiet w czasie powstania styczniowego 1863-1864 (Na tle polskich konspiracji i działalności powstańczej doby zaborowej), pod red. T. Kulak, J. Dufrat, M. Piotrowskiej-Marchewy, Wrocław 2013, s. 163-189.

Caban, W., Michalska-Bracha L., „Orenburski domek” Stanisława Miaskowskiego. Z badań nad lwowska kolekcją listów zesłańca postyczniowego (1863-1867), [w:] Zesłańcy postyczniowi w Imperium Rosyjskim. Studia dedykowane profesor Wiktorii Śliwowskiej, red. E. Niebelski, Lublin-Warszawa 2008, s. 177-190. 
Groniowski K., Emigracja z ziem zaboru rosyjskiego (1864-1918), [w:] Emigracja z ziem polskich w czasach nowożytnych (XVIII-XX w.), red. A. Pilch, Warszawa 1984, s. 223-230.

Kijas A., Polacy w Rosji od XVII wieku do 1917 roku. Słownik biograficzny, Warszawa-Poznań 2000.

Kumor B., Kościól i katolicy w cesarstwie rosyjskim (do 1918 roku), [w:] Odrodzenie Kościoła katolickiego w bytym ZSRR, red. E. Walewander, Lublin 1993.

Latypowa W.W., Poljaki na Jużnom Urale (XVII - naczało XX weka). Oczerki istoriko-kul'turnogo nasledija, Ufa 2010.

Latypowa W.W., Polskije ssylnye na Jużnom Urale posl'e wosstanija 1863-1864 godow i ich wzaimootnoszenija c mestnym naseleniem, [w:] Polacy a Rosjanie. Materiaty z konferencji „Polska-Rosja. Rola polskich powstań narodowych w kształtowaniu wzajemnych wyobrażeń". Warszawa-Płock, 14-17 maja 1998, pod red. T. Epszteina, Warszawa 2000, s. 278-279.

Łukawski Z., Polacy w Rosji: 1863-1914, Wrocław-Warszawa-Kraków 1978.

Niewiara A., Moskwicin-Moskal-Rosjanin w dokumentach prywatnych. Portret, Łódź 2006.

Pająk J. Z., Szczepański J., Problemy identyfikacji i interpretacji źródeł pamiętnikarskich z ziem zabranych w XIX w. (casus Jana Bispinga i Jana Witorta), [w:] Polskie dziewiętnastowieczne pamiętniki i listy z Ziem Zabranych - rola i miejsce $w$ badaniach historycznych, red. W. Caban i L. Michalska-Bracha, Warszawa 2017.

Poljaki w Piermskom kraie: oczerki istorii i etnografii, Sankt Peterburg 2009.

Sikorska-Kulesza J., Dzieciństwo i młodość a tożsamość narodowa. Wspomnienia Władysława Zahorskiego, „Rocznik Stowarzyszenia Naukowców Polaków Litwy” 2011/2012, t. 10/11, s. 6-26. 